\title{
The United States — China Rivalry and the BRI
}

\author{
Jean-Marc F. Blanchard \\ East China Normal University, Shanghai, China; \\ Mr. \& Mrs. S.H. Wong Center for the Study of Multinational Corporations, USA \\ \executive_director@mnccenter.org
}

\begin{abstract}
The article describes the United States - China rivalry and China's Belt and Road Initiative (BRI) through a fine-grained review of primary materials such as major US policy documents and speeches by and media interviews with key American foreign policy decisionmakers, as well as the selective use of secondary materials such as think tank studies and articles in scholarly publications. It shows that the BRI has fueled the bilateral rivalry since its birth in 2013 and that the rivalry, in turn, has affected US views about the BRI. Under President Barack Obama, the US took a muted stance towards the BRI, expressing modestly cooperative sentiments regarding it. In contrast, under President Donald Trump, Washington's posture towards the BRI dramatically changed with his administration frequently denigrating the BRI, raising it in major security and foreign policy documents, initiating competing development schemes such as the BUILD Act, and building closer cooperation with allies against China's venture. Despite its angst about the BRI, however, the Trump administration never launched any large-scale countermeasures. This article contributes to clarifying the situation by correcting some factual errors in past analyses and updating the general understanding about the Trump administration's response. It systematically contemplates how internal and external economic, political, and ideational factors affected the Obama and Trump administration's responses to the BRI, demonstrating that such factors shaped or shifted US policy or bounded its form and intensity. These factors, being similar to those stressed by neoclassical realists who emphasize the role of leaders as interpreters within limits of the external environment and responders to it subject to various domestic constraints, provide a foundation which is used to speculate about the US's probable response to the BRI under President Joseph Biden, Jr.
\end{abstract}

Key words: China, United States, Belt and Road Initiative, BRI, US - China rivalry

For citation: Blanchard, J.-M.F. (2021). The United States - China Rivalry and the BRI. Vestnik RUDN. International Relations, 21(2), 288-303. https://doi.org/10.22363/2313-0660-2021-21-2-288-303

\section{Американо-китайское соперничество и инициатива «Один пояс, один путь»}

\author{
Ж.-М.Ф. Бланшар \\ Восточно-китайский педагогический университет, Шанхай, Китай; \\ Центр изучения транснациональных корпораций им. г-на и г-жи С.Х. Вонг, США \\ 冈executive_director@mnccenter.org
}

Аннотация. Рассматриваются отношения США и КНР в контексте соперничества государств, а также прослеживается влияние подобного уровня взаимодействия на китайскую инициативу «Один пояс, один путь» (ОПОП). Методологически автор опирается на анализ первоисточников, таких как основные политические документы, выступления представителей политического истеблишмента США, интервью в СМИ с ключевыми лицами, принимающими внешнеполитические решения, а также на выборочное использование

(C) Blanchard J.-M.F., 2021

This work is licensed under a Creative Commons Attribution 4.0 International License.

https://creativecommons.org/licenses/by/4.0/ 
вспомогательных материалов, таких как исследования аналитических центров и статьи в научных журналах. Автор полагает, что с момента создания в 2013 г. ОПОП стимулирует конкуренцию в отношениях двух стран, и это, в свою очередь, не может не влиять на подход США к самой инициативе. Во время президентства Б. Обамы Вашингтон занимал довольно сдержанную позицию по отношению к китайской инициативе, демонстрируя умеренную открытость к сотрудничеству с Пекином. Однако подобный подход сменился более жесткой политикой при президенте Д. Трампе. При упоминании проекта в основных документах по безопасности и внешней политике новая республиканская администрация, по сути, сделала ставку на обесценивание ОПОП, инициируя конкурентные схемы развития, такие как Закон о более эффективном использовании инвестиций, ведущих к развитию, и наладив более тесное сотрудничество с союзниками против проекта Китая. Несмотря на возросшую степень беспокойства в отношении инициативы, администрация Д. Трампа так и не предприняла никаких крупномасштабных контрмер. Также объясняется, каким образом экономические, политические и идеологические факторы внутреннего и внешнего характера повлияли на подходы администраций Б. Обамы и Д. Трампа к ОПОП в части определения или изменения политики США или ограничения ее формата и интенсивности. Данные факторы, наподобие тех, о которых говорят представители неоклассического реализма, в частности роль лидеров, лежат в основе оценки ОПОП в период президентства Дж. Байдена. и Китая

Ключевые слова: Китай, США, инициатива «Один пояс, один путь», ОПОП, соперничество США

Для цитирования: Blanchard J.-M.F. The United States - China Rivalry and the BRI // Вестник Российского университета дружбы народов. Серия: Международные отношения. 2021. T. 21. № 2. C. 288-303. DOI: 10.22363/2313-0660-2021-21-2-288-303

\section{Introduction}

Many issues have featured in the rivalry between the United States (US) and the People's Republic of China (the PRC/China) and its dramatic intensification during the Donald Trump presidency. A short list includes COVID-19, US - China competition in the South China Sea, PRC activism in various regions of the world such as Latin America and Africa, human rights, Hong Kong, Taiwan, and US restrictions on foreign direct investment (FDI) by Chinese companies. In addition, domestic political factors such as increased antiPRC sentiments in the American Congress and the shift towards a more authoritarian political environment in China have created as well as fueled greater bilateral frictions [Medeiros 2019; Goldstein 2020; Yung 2021]. After Joseph Biden Jr. won his campaign for the US presidency, many have opined - typically in very general terms - about its potential implications for US policy towards China with respect to these and other areas such as Iran, climate change, and tariffs ${ }^{1}$.

\footnotetext{
${ }^{1}$ See: Dasgupta S. Will Biden Reverse Trump's China Policies // VOA. January 22, 2021. URL: https://www.voanews.com/east-asia-pacific/will-bidenreverse-trumps-china-policies (accessed: 19.02.2021);
}

Less than a handful of writers, though, have speculated about the stance that Biden will adopt towards China's marquee Belt and Road Initiative (BRI). One opinion implies Biden will embrace a hostile posture towards it because of the adverse implications of many BRI projects on climate change ${ }^{2}$. Another stance sees budgetary limitations preventing Biden from initiating any major challenges to the $\mathrm{BRI}^{3}$. Yet

Weaver A.E. Biden Won't Deal with Xi or China like Trump Did // Politico. February 7, 2021. URL: https://www.politico.com/news/2021/02/07/biden-chinaxi-jinping-466761 (accessed: 19.02.2021); Swanson A. Biden on 'Short Leash' as Administration Rethinks China Relations // The New York Times. February 17, 2021. URL: https://www.nytimes.com/2021/02/17/business/ economy/biden-china.html (accessed: 19.02.2021).

${ }^{2}$ See: Swaminathan A. Biden Is Relentless on One China Issue: The New Silk Road // Yahoo!Life. February 25, 2020. URL: https://www.yahoo.com/lifestyle/bidenchina-climate-change-new-silk-road-143657484.html (accessed: 19.02.2021); Lee Y.N. Biden's Focus on Climate Change Could Turn up the Pressure on China's Mega Infrastructure Program // CNBC. January 14, 2021. URL: https://www.cnbc.com/2021/01/14/climate-changebiden-could-up-pressure-on-chinas-belt-and-roadinitiative.html (accessed: 19.02.2021).

${ }^{3}$ Gupta S. Putting a Blue Collar on Biden's Trade Policy // East Asia Forum. February 1, 2021. URL: https://www.eastasiaforum.org/2021/02/01/putting-a-bluecollar-on-bidens-trade-policy (accessed: 19.02.2021). 
another envisions unceasing US "paranoia" about the BRI and a "hybrid war on China... all over the spectrum" ${ }^{\prime 4}$. None of these suggestions reflect reliable, in-depth analysis and neither the new US President nor any of his Cabinet members have issued any public comments that would clarify the Biden administration's stance towards the BRI.

Unfortunately, this leaves a gap in our understanding of Washington's future posture towards an issue that represents one of the many thorns in the US - China relationship. Biden's BRI strategy also has policy relevance because of its likely significant implications for individual countries, regional groupings such as the Association of Southeast Asian Nations, and international institutions. Beyond this, policy elites clearly remain animated about the BRI ${ }^{5}$. Grasping Biden's BRI stance has ramifications for businesses, too, since his policy could affect their ability to sell goods and services and work with certain partners, and their FDI environment. From an analytical standpoint, comprehending the variables that might affect Biden's stance towards the BRI is useful, since it could shed light on the factors driving American foreign policy, Sino-American relations, and the response of states to external politico-economic challenges.

Drawing upon primary materials such as major US policy documents and speeches and media interviews with key foreign policy decisionmakers, as well as the selective use of secondary materials such as expert commentary, think tank reports, and academic articles, this study examines the US's responses to the BRI under the Barack Obama and Donald Trump presidencies and contributes to our knowledge by updating and correcting past research as shown below. More importantly, the paper evaluates in a consistent and systematic way the drivers of

${ }^{4}$ Escobar P. Belt and Road Paranoia will Rumble on under Biden // Asia Times. December 9, 2020. URL: https://asiatimes.com/2020/12/belt-and-road-paranoia-willrumble-on-under-biden (accessed: 19.02.2021).

${ }^{5}$ See, e.g.: Webb J. An American Belt and Road Initiative? // Wall Street Journal. February 17, 2021. URL: https://www.wsj.com/articles/an-american-belt-and-roadinitiative-11613603381 (accessed: 19.02.2021).
US policy towards the BRI during these two administrations to provide a basis for forecasting Washington's future BRI policy.

In terms of findings, it shows that the Obama administration, while quite aware of the BRI, did not put forth any substantive response to it. It contends that this resulted from, among other things, the administration's focus on other priorities, generally positive view of the BRI, and propensity to view the BRI in the context of Central Asia. It further demonstrates that the Trump administration embraced a sustained and more vigorous - though far from highly aggressive - response to the BRI. It contends this flowed from, inter alia, structural factors such as the administration's heightened sense of a China threat, perception an accommodative stance towards China would not be worthwhile, and a development ideology privileging private investment. This analysis, therefore, bears similarities to neoclassical realist approaches which emphasize the role of leaders as interpreters, within limits, of the external environment and responders to it subject to domestic constraints [Rose 1998; Rathbun 2008; Lobell, Ripsman, Taliaferro 2009].

The next (second) section delivers a general overview of the BRI. The third section offers background on the Obama administration's reaction to the BRI and offers some thoughts about the factors driving it. The fourth section provides a detailed treatment of the Trump administration's response looking at facets such as its rhetoric, its initiation of countervailing development options, and its efforts to work with US allies and partners. It also presents an analysis of the drivers of the Trump's administration's posture towards the BRI. The fifth and final section concludes with a summary of some of the article's key findings, a discussion of their policy and business implications, and an identification of areas needing additional research.

\section{Traversing the BRI, a Primer}

China's BRI, which consists of the landoriented Silk Road Economic Belt (SREB) and the sea maritime-oriented Maritime Silk Road 
Initiative (MSRI), was launched in 2013. Chinese President Xi Jinping's announcement of the BRI drew considerable attention because of its immense geographic scope, prospective financial scale and potentially earthshaking political and economic implications. China's massive connectivity plan included dozens of countries with the land-based segment running from China through Central Asia and Russia into Eastern and Central Europe and eventually Western Europe. For its part, the sea-based segment would traverse from China through Southeast Asia to South Asia, Africa, the Middle East, and Africa before eventually moving into Western Europe. Funding — entailing aid, Chinese outward FDI (OFDI), and loans - was estimated to exceed 1 trillion USD, though there continues to be much confusion about the amount of money actually associated with the BRI [Blanchard 2018a, 2019, 2021a, 2021b].

The BRI's most dramatic feature is largescale, tangible infrastructure such as airports, bridges, high-speed railways, roads, seaports, and subways. However, as case studies of the BRI in South Asia, Southeast Asia, and Africa and the Middle East show, BRI tangible infrastructure goes far beyond connectivity infrastructure to include dams, power generation systems and distribution lines, industrial and special economic zones, gas and oil pipelines, and telecommunications networks. Soft infrastructure is an important component of the BRI, too, though it receives scant attention. Relevant BRI soft infrastructure includes taxation agreements, accords pertaining to customs clearance and phytosanitary standards, civil aviation treaties, regional free trade agreements, and bilateral investment treaties [Blanchard 2018a: 332; Blanchard 2018b; Blanchard 2019; Flint, Zhu 2019; Blanchard 2021b].

There is no definitive exposé of China's purpose behind launching the BRI. Analysts contend it aims to fulfill multiple international and domestic political and economic purposes. On the international political front, it is believed that China aims to use the BRI to deepen political ties with other countries (or worse ensnare them), to improve its resource security and supply chains, and to prevent terrorism. In the international economic sphere, commentators view China's BRI as a tool to inter alia expand exports, increase business opportunities for Chinese multinational corporations (MNCs), and stimulate use of its currency the renminbi. As for the domestic political arena, some feel the BRI has the potential to undercut parochial behaviors by various provinces and cities. Moving to the domestic economic front, many observers believe the BRI seeks to accelerate development in backward areas such as China's southwest and help China move up the industrial value-added chain [Wang 2016; Blanchard 2018a: 333-335; Zhao 2020].

It is highly debatable that the BRI will be fully embraced by all, implemented in its entirety, or all its expected benefits fully delivered [Blanchard 2018a; Chen 2018]. Assuming all this happens, then the BRI could have serious ramifications for the military, political, and economic interests of others such as the US, Japan, and India. For instance, it could bolster China's influence over flows of energy, information, raw materials, intermediate and final goods, and people. In addition, it could give China a leading or perhaps even dominant role in regions such as Southeast Asia, South Asia, or the Middle East. Furthermore, it could tie individual countries tightly to China and by increasing their dependence on Beijing and/or decrease the appeal of others causing political and economic troubles for the latter. Beyond this, it could ensconce the position of PRC contractors, investors, lenders, suppliers and service providers, and technical standards at the expense of other countries' MNCs and technical standards. Finally, it could reshape the Western trade, investment, and financial norms.

In light of these potential implications, countries such as India and Japan have adopted various countermeasures. For instance, India has worked to improve its political and economic ties with neighboring countries such as Maldives, Nepal, and Sri Lanka. It also has criticized the BRI and launched its own (relatively unimpressive) infrastructure scheme called Project Mausam [Blanchard 2018b]. For its part, Japan launched its own major initiative called the 
Partnership for Quality Infrastructure Initiative (PQII) which promises 110 bln USD in funding from various Japanese financial institutions and Asia Development Bank (ADB) for Asian infrastructure. Japan has also built stronger linkages with India, Australia, and the US in an effort to offer an alternative to the BRI and call attention to some of its various defects ${ }^{6}$. It is to the US response that we now turn.

\section{The US Response to China's BRI under President Barack Obama}

This section discusses US President Obama's response to the BRI, which appeared on the scene during the first year of his second term in office. Worth noting, in 2011, his administration had already promulgated its own Silk Road venture, termed the New Silk Road Initiative (NSRI), which was far less ambitious in almost every respect than China's scheme. Afghanistan coupled with regional energy and transportation infrastructure was the core of the NSRI story in no small part because of Washington's desire to foster the troubled country's development as well as integration among Central and South Asia's integration. The NSRI's marquee project was the Central Asia South Asia Electricity Transmission and Trade project (CASA-1000), a 1.2 bln USD electricity transmission $\operatorname{grid}^{7}$. The NSRI, though, eventually died due to a lack of adequate funding, resources, and US political commitment to the endeavor ${ }^{8}$.

The Obama administration was attentive to China's BRI endeavor, commented generally about it and associated areas like China's

\footnotetext{
${ }^{6}$ Harris T. 'Quality Infrastructure': Japan's Robust Challenge to China's Belt and Road // War on the Rocks. April 9, 2019. URL: https://warontherocks.com/2019/ 04/quality-infrastructure-japans-robust-challenge-tochinas-belt-and-road (accessed: 19.02.2021).

${ }^{7}$ Zimmerman T. The New Silk Roads: China, the U.S., and the Future of Central Asia // New York University Center on International Cooperation. October 2015. P. 14-15. URL: https://cic.nyu.edu/sites/default/files/ zimmerman_new_silk_road_final_2.pdf (accessed: 19.02.2021).

${ }^{8}$ Delaney R. Lessons for China in Failed US Silk Road Initiative // South China Morning Post. May 8, 2017. URL: https://www.scmp.com/news/china/diplomacy-defence/ article/2092218/lessons-china-failed-us-silk-road-initiative (accessed: 19.02.2021).
}

infrastructure activities, and exuded a moderately cooperative tone towards such activities (albeit without expressly mentioning the BRI). Illustrating the first dimension, in mid-April 2016, an US Department of State (DoS) Special Representative remarked the administration "continue[d] to engage Chinese officials on the Belt and Road Initiative... so that we can better understand China's priorities, and determine whether there are areas of mutual benefit"".

Exemplifying the second dimension, a White House Fact Sheet issued at the end of President Xi's visit to Washington in late September 2015 stated, "The United States welcomes China's growing contributions to financing development and infrastructure in Asia and beyond" 10 . Reflective of the second and third dimensions, about three weeks after $\mathrm{Xi}$ promulgated the BRI, a DoS official with the Bureau of South and Central Asian Affairs said: "We welcome the efforts of China to develop energy and transportation infrastructure in the region... We see all these efforts as mutually reinforcing and beneficial to the Central Asia countries and Afghanistan... We believe that there is plenty of work to go around"11.

Similarly, six months before Obama hosted $\mathrm{Xi}$ in Washington, US Deputy Secretary of State Tony Blinken opined the US did not "see China's involvement in Central Asia in zero-sum terms' and that China infrastructure investments were complementary to those of the US" ${ }^{\prime 2}$.

\footnotetext{
${ }^{9}$ Remarks at the Asia-Pacific Council of American Chambers of Commerce (APCAC) Gala Dinner // US Department of State. April 14, 2016. URL: https://20092017.state.gov/e/eb/rls/rm/2016/255825.htm (accessed: 29.01.2021).

${ }^{10}$ Fact Sheet: U.S. - China Economic Relations // The White House. Office of the Press Secretary. September 25, 2015. URL: https://obamawhitehouse.archives.gov/ the-press-office/2015/09/25/fact-sheet-us-china-economicrelations (accessed: 29.01.2021).

${ }^{11}$ Tracy L.M. The United States and the New Silk Road // US Department of State. October 25, 2013. URL: https://2009-2017.state.gov/p/sca/rls/rmks/2013/215906.htm (accessed: 29.01.2021).

${ }^{12}$ Zimmerman T. The New Silk Roads: China, the U.S., and the Future of Central Asia // New York University Center on International Cooperation. October 2015. P. 16. URL: https://cic.nyu.edu/sites/default/files/ zimmerman_new_silk_road_final_2.pdf (accessed: 19.02.2021).
} 
The Obama administration did not proffer any explicit or strong criticisms of the BRI. Still, it raised concerns indirectly and directly. For instance, in April 2015, Mr. Obama said: "To the extent that China wants to put capital into development projects around the region, that's a positive, [but there was a] need for adherence to best practices... and for projects to benefit local populations and not just the leaders of some countries and contractors" $"$.

The next month, a DoS Assistant Secretary of State observed, directly commenting on the BRI and other Eurasian integration schemes, that the US wanted "a more connected region". However, trade needed to be "inclusive, multidirectional, and rules-based" 14 .

The available evidence does not support claims that the Obama administration never spoke publicly about the BRI or directly mentioned it. In any event, it is apparent that it was not a high priority. In this vein, one writer points out that "the BRI [was] never covered during the US - China Strategic and Economic Dialogue during the Obama years" ${ }^{15}$. Moreover, the public record does not show any substantive countermeasures by the administration. As one American researcher succinctly puts it, the "responses to the BRI under the Obama administration... were benign", focusing on cooperation $^{16}$. Aside from this, the content of the remarks by administration representatives makes clear that the administration seems to have viewed China's initiative primarily through the lenses of its potential implications for Central Asia and Afghanistan rather than other regions or the entire globe.

\footnotetext{
${ }^{13}$ Lawrence S., Nelson G.M. China's 'One Belt, One Road // Congressional Research Service in Focus. August 6, 2015. P. 2. URL: https://crsreports.congress.gov/ product/details?prodcode=IF10273 (accessed: 29.01.2021).

${ }^{14}$ Ibid.

${ }^{15}$ Luft G. Silk Road 2.0: A US Strategy toward China's Belt and Road Initiative // Atlantic Council Strategy Paper. October 2017. No. 11. P. 4. URL: https://www.atlanticcouncil.org/wp-content/uploads/2017/ 10/US_Strategy_toward_Chinas_BRI_web_1003.pdf (accessed: 19.02.2021).

${ }^{16}$ Wuthnow J. From Friend to Foe-Ish: Washington's Negative Turn on the Belt and Road Initiative // The Asan Forum. May 21, 2018. URL: www.theasanforum.org/fromfriend-to-foe-ish-washingtons-negative-turn-on-the-beltand-road-initiative (accessed: 19.02.2021).
}

There were several conceivable factors driving the Obama administration's stance. The administration was likely focused on other pressing matters such as Afghanistan, Iran, and climate change ${ }^{17}$.

Secondly, it viewed the BRI not only as a way to advance its objectives in Afghanistan and Central Asia, but also non-threatening in the context of Central Asia given the number of competing powers and contending regional infrastructure schemes there as well as the region's relatively low priority to the US.

Thirdly, it would be odd, per one commentator, for the US to criticize China for trying to do something it tried to do [Starr 2019: 79-91].

Fourthly, the administration might have failed to appreciate the full implications of China's initiative, though, to be fair, its ramifications were quite murky given that even as late as 2015 and 2016 many BRI projects had not started, finished, or produced effects. Moreover, for Obama, the PRC foreign policy initiative that most likely presented the biggest threat was the Regional Comprehensive Economic Partnership ${ }^{18}$.

Finally, Obama's proclivity to favor cooperation during his early years in office and his generally non-confrontational posture towards China for much of his tenure may have tempered his administration's BRI policies.

\section{The US's BRI Response under President Donald Trump}

This section reviews the Trump administration's reaction to the BRI. For a short period, its stance towards the BRI was positive, far from "unequivocal in its opposition to Beijing's infrastructural development project" as one assessment claimed [Ashbee 2020: 375]. For example, at a White House press conference in early May, a spokesperson said, the US was

17 Ibid.

${ }^{18}$ Gan N., Delaney R. United States under Donald Trump is Veering Away from China's Belt and Road // South China Morning Post. April 25, 2019. URL: https://www.scmp.com/news/china/article/3007504/unitedstates-under-trump-veering-away-chinas-belt-and-road (accessed: 19.02.2021). 
"considering cooperation under the BRI as it is a 'major trade initiative' and 'obviously, trade is a major issue for us'". In the wake of Trump's summit with $\mathrm{Xi}$, the US and China issued a 100-day action plan under the framework of the US - China Comprehensive Economic Dialogue. The 10th item on the list of initial actions noted: the US "recognizes the importance of China's One Belt and One Road initiative and is to send delegates to attend the Belt and Road Forum [BRF] in Beijing May 14-15"19.

The US eventually sent then National Security Council (NSC) Senior Director for Asia Matt Pottinger, who, in Beijing, stated "US firms... are ready to participate in Belt and Road projects" ${ }^{20}$. The next month during a meeting with PRC State Councilor Yang Jiechi, Trump reportedly said the US "is willing to conduct cooperation in relevant projects of the BRI"21. Nonetheless, the administration's position towards the BRI appears to have been a little muddled $^{22}$. Illustrating this, it sent Pottinger, a relatively low-level official, to the $2017 \mathrm{BRF}$ and while in Beijing he stressed the need for China to ensure transparency in the bidding for BRI projects. Yet, while in Beijing, Pottinger also announced the formation of a business-US Embassy (Beijing) working group to facilitate US involvement in the $\mathrm{BRI}^{23}$.

19 Joint Release: Initial Results of the 100-Day Action Plan of the U.S. - China Comprehensive Economic Dialogue // US Department of Commerce. May 11, 2017. URL: https://agdc.us/wp-content/uploads/2017/05/JOINTRELEASE_-Initial-Results-of-the-100-Day-Action-Planof-the-U.S.pdf (accessed: 29.01.2021).

${ }^{20}$ Wuthnow J. From Friend to Foe-Ish: Washington's Negative Turn on the Belt and Road Initiative // The Asan Forum. May 21, 2018. URL: www.theasanforum.org/fromfriend-to-foe-ish-washingtons-negative-turn-on-the-beltand-road-initiative (accessed: 19.02.2021).

21 US President Donald Trump Meets with Yang Jiechi // PRC, Ministry of Foreign Affairs (MOFA). June 23, 2017. URL: https://www.fmprc.gov.cn/mfa eng/ Zxxx 662805/t1473199.shtml (accessed: 29.01.2021).

${ }^{22}$ Luft G. Silk Road 2.0: A US Strategy toward China's Belt and Road Initiative // Atlantic Council Strategy Paper. October 2017. No. 11. P. 10. URL: https://www.atlanticcouncil.org/wp-content/uploads/2017/ 10/US_Strategy_toward_Chinas_BRI_web_1003.pdf (accessed: 19.02.2021).

${ }^{23}$ See: Zhao H. US Forms Belt, Road Group // China Daily. May 16, 2017. URL: http://www.chinadaily.com.cn/

\section{Slam and Slights}

It did not take long for the administration to embrace a clear, public, and increasingly negative stance towards China's endeavor, though it was not always explicit. The first week of October 2017, then Secretary of Defense James Mattis stated in response to a question about the BRI during a US Senate hearing that "there are many belts and roads, and no one nation should put itself into a position of dictating 'One Belt, One Road' (OBOR)"'24. Two weeks later, during a policy speech on US India relations, then US Secretary of State Rex Tillerson highlighted how Chinese projects and associated financing did not create jobs for locals, imposed burdensome debts, and made borrowers vulnerable to losing valuable assets ${ }^{25}$. During a visit to Beijing in November, Trump reportedly was silent about the BRI even though $\mathrm{Xi}$ spoke about it during their conversations. Subsequently, in Vietnam, "Trump implicitly criticized the BRI" by distinguishing between US programs and "state-directed initiative that comes with many strings attached"26. On December 13, speaking to US DoS employees at a town hall, Tillerson said: "We do pay close attention to their OBOR policy" and, paraphrasing Mattis, added: "China has One Belt, One Road; the United States and the global

newsrepublic/2017-05/16/content_29374081.htm (accessed: 19.02.2021); Hsu S. Trump's Support for China's One Belt, One Road Initiative is Bad for U.S., Good for World // Forbes. May 18, 2017. URL: https://www.forbes. com/sites/sarahsu/2017/05/18/trumps-support-for-chinasone-belt-one-road-initiative-is-bad-for-u-s-good-forworld/?sh=351874f83402 (accessed: 19.02.2021).

${ }^{24}$ Political and Security Situation in Afghanistan // US Senate, Committee on Armed Services. October 3, 2017. P. 61-62. URL: https://www.armed-services.senate.gov/imo/ media/doc/17-82 10-03-17.pdf (accessed: 29.01.2021).

${ }^{25}$ Defining Our Relationship with India for the Next Century: An Address by U.S. Secretary of State Rex Tillerson // CSIS. October 18, 2017. URL: https://www.csis.org/analysis/defining-our-relationshipindia-next-century-address-us-secretary-state-rex-tillerson (accessed: 29.01.2021).

${ }^{26}$ Wuthnow J. From Friend to Foe-Ish: Washington's Negative Turn on the Belt and Road Initiative // The Asan Forum. May 21, 2018. URL: www.theasanforum.org/fromfriend-to-foe-ish-washingtons-negative-turn-on-the-beltand-road-initiative (accessed: 19.02.2021). 
economy have many belts and many roads, and no one country gets to choose the belt or the road". He also noted it was unclear if the BRI would be implemented within existing global rules and norms or try to redefine them ${ }^{27}$.

The administration advanced similar kinds of criticism throughout 2018. In mid-February, the then Commander of the US Pacific Command asserted that the BRI was a "concerted, strategic endeavor by China to gain a foothold and displace the United States" as well as its regional allies and partners, and was putting "global chokepoints under pressure" 28 . In mid-November, at the Asia-Pacific Economic Cooperation summit, former US Vice President Mike Pence derided the BRI and the PRC's assorted infrastructure activities in strong, albeit indirect terms. Some of the most emotive content in his remarks includes: "Some are offering infrastructure loans... Yet the terms of those loans are often opaque at best. Projects they support are often unsustainable and of poor quality. And too often, they come with strings attached and lead to staggering debt... Know that the United States offer a better option. We don't drown our partners in a sea of debt. We don't coerce or compromise your independence... We do not offer a constricting belt or a one-way road" 29 .

In March 2019, then Secretary of State Mike Pompeo implied the BRI had a "state national security element" and also that it involved "noneconomic offers" and "predatory lending" and

${ }^{27}$ US Says Paying Attention to OBOR, but Doesn't Want to Contain China's Growth // Hindustan Times. December 13, 2017. URL: https://www.hindustantimes. com/world-news/us-says-paying-attention-to-obor-butdoesn-t-want-to-contain-china-s-growth/storyxY3vo9kEBgbmdd5FteXj1M.html (accessed: 19.02.2021).

${ }^{28}$ All Global Chokepoints under OBOR Pressure: Admiral Harris // The Economic Times. February 15, 2018. URL: https://economictimes.indiatimes.com/news/ defence/all-global-chokepoints-under-obor-pressure-

admiral-harris/articleshow/62926472.cms (accessed: 19.02.2021).

${ }^{29}$ Remarks by Vice President Pence at the 2018 APEC CEO Summit // US White House. November 16, 2018. URL: https://trumpwhitehouse.archives.gov/briefingsstatements/remarks-vice-president-pence-2018-apec-ceosummit-port-moresby-papua-new-guinea (accessed: 29.01.2021). that the US DoS was going to make sure that others saw it and identified $i^{30}$. The following month China hosted the 2nd BRF, which the US slighted by not sending any representatives. In September, Pompeo opined the BRI is part of a scheme to "try and create vassal states" ${ }^{31}$. In October, then US Commerce Secretary Wilbur Ross charged that the BRI "use[d] Chinese materials and Chinese nationals to build projects with very little local content" and that the BRI was "effectively a jobs program for China" 32 . In late November 2019, US Ambassador Alice Wells raised a familiar litany of concerns about Chinese projects ranging from transparency to irresponsible lending to corruption to a failure to use local labor to a failure to embrace international standards. She also asserted one root of BRI's shortcomings was China's focus on "solving its own domestic problems... sometimes at the expense of the receiving country" 33 .

\section{Strategizing about the BRI}

Key Trump administration policy documents such as the 2017 National Security Strategy (hereinafter 2017 NSS), 2018 "Strategic Framework for the Indo-Pacific" (hereinafter 2018 Strategic Framework), and 2020 DoS "Elements of the China Challenge" policy paper

\footnotetext{
${ }^{30}$ Conversation with Rich Lowry at the National Review Institute's 2019 Ideas Summit // US Department of State. March 28, 2019. URL: https://2017-2021.state.gov/ conversation-with-rich-lowry-at-the-national-review-

institutes-2019-ideas-summit/index.html (accessed: 29.01.2021).

${ }^{31}$ Secretary Michael R. Pompeo with Lou Dobbs of Lou Dobbs Tonight // US Department of State. September 1, 2020. URL: https://2017-2021.state.gov/ secretary-michael-r-pompeo-with-lou-dobbs-of-lou-dobbstonight/index.html (accessed: 29.01.2021).

${ }^{32}$ Remarks by Secretary Wilbur Ross at the Federalist Society // Just the Real News. October 15, 2019. URL: https://www.justtherealnews.com/exec-depts/remarks-bysecretary-wilbur-ross-at-the-federalist-society/ (accessed: 29.01.2021).

${ }^{33}$ A Conversation with Ambassador Alice Wells on the China - Pakistan Economic Corridor // US Department of State. November 21, 2019. URL: https://2017-2021.state. gov/a-conversation-with-ambassador-alice-wells-on-thechina-pakistan-economic-corridor/index.html (accessed: 29.01.2021).
} 
(hereinafter 2018 Elements paper), which make explicit mention of China's BRI, infrastructure, and Chinese OFDI (COFDI), constitute another part of the administration's BRI response ${ }^{34}$. These documents indisputably have a rhetorical element to them since they directly and indirectly malign China's BRI, infrastructure, and FDI. As well, they raise alarm about Chinese efforts to use COFDI, infrastructure, and loans to gain preeminence in various functional realms (e.g., international economic governance) and geographic areas, negatively influence the access of other parties to such areas, foster dependencies, promote Chinese digital surveillance technologies, and undermine international norms. Still, these documents play far more than a stigmatizing role since they also function to highlight US concerns, prioritize US government political, military, and economic activities, coordinate US government agencies, send a message to US allies and partners, and identify general policies to accomplish US priorities.

Illustrating the derogatory function of such documents and their role in highlighting US concerns, the 2017 NSS states that China uses "investments in the developing world to expand influence and gain competitive advantages against the United States" and that "China's infrastructure investments and trade strategies reinforce its geopolitical aspirations" 35 . For its part, the 2018 Elements paper opines that the BRI is one of China's tools to "expand foreign markets for Chinese companies and... a means

\footnotetext{
${ }^{34}$ See: National Security Strategy of the United States of America // US White House. December 2017. URL: https://rumpwhitehouse.archives.gov/wp-content/uploads/ 2017/12/NSS-Final-12-18-2017-0905.pdf (accessed: 29.01.2021); United States Strategic Framework for the Indo-Pacific [Secret] // US White House. February 15, 2018. URL: https://trumpwhitehouse.archives.gov/wpcontent/uploads/2021/01/IPS-Final-Declass.pdf (accessed: 29.01.2021); The Elements of the China Challenge // US DoS, Policy Planning Staff. November 2020. URL: https://www.state.gov/wp-content/uploads/2020/11/2002832-Elements-of-China-Challenge-508.pdf (accessed: 29.01.2021).

${ }^{35}$ National Security Strategy of the United States of America // US White House. December 2017. P. 38, 46. URL: https://trumpwhitehouse.archives.gov/wp-content/ uploads/2017/12/NSS-Final-12-18-2017-0905.pdf (accessed: 29.01.2021).
}

of drawing nationals... into Beijing's geopolitical orbit" and that China's infrastructure projects often "entrench China's long-term access to local elites and confer power over key parts of the host country's critical infrastructure" 36 . The paper also remarks that "Beijing provides digital technology and physical infrastructure to advance the Chinese Communist Party's authoritarian objectives throughout the [Indo-Pacific] region" 37 .

The aforementioned three documents devote (repeated) attention to development finance highlighting Washington's concerns and priorities and messaging allies and partners and offer some general policy proposals. For instance, the 2017 NSS says that the US will "modernize its development finance tools so that U.S. companies have incentives to capitalize on opportunities in developing countries"38. It further remarks that the US and its partners must "encourage multilateral development banks to invest in high-quality infrastructure projects that promote economic growth" 39 . The 2020 Elements paper stresses that the US must exploit "initiatives such as the International Development Finance Corporation [IDFC] and emerging Blue Dot Network to invest in friendly nations' physical and digital infrastructure and commercial ventures, especially in the Indo-Pacific region" 40 .

In terms of sending a message to allies and partners, setting priorities, and proposing general policy directions, the 2017 NSS states, "we will strengthen cooperation with allies on high-

${ }^{36}$ The Elements of the China Challenge // US DoS, Policy Planning Staff. November 2020. P. 12. URL: https://www.state.gov/wp-content/uploads/2020/11/2002832-Elements-of-China-Challenge-508.pdf (accessed: 29.01.2021).

${ }^{37}$ Ibid. P. 17.

${ }^{38}$ National Security Strategy of the United States of America // US White House. December 2017. P. 39. URL: https://trumpwhitehouse.archives.gov/wp-content/uploads/ 2017/12/NSS-Final-12-18-2017-0905.pdf (accessed: 29.01.2021)

${ }^{39}$ Ibid. P. 41.

${ }^{40}$ The Elements of the China Challenge // US DoS, Policy Planning Staff. November 2020. P. 47-48. URL: https://www.state.gov/wp-content/uploads/2020/11/20-

02832-Elements-of-China-Challenge-508.pdf (accessed: 29.01.2021). The IDFC and Blue Dot Network are discussed below. 
quality infrastructure" ${ }^{\prime 1}$. It notes, too, that the US will encourage regional cooperation to "maintain transparent infrastructure financing practices" 42 . The 2018 Strategic Framework mentions that in the Indo-Pacific the US will "build regional support for US - India Common principles... including transparent infrastructure-debt practices" while in Southeast Asia and the Pacific Islands the US will "promote an integrated economic development model in the Indo-Pacific that provides a credible alternative to One Belt One Road"43.

\section{Dueling Development Deals}

On the development front, the Trump administration had three noteworthy responses to the BRI - the Better Utilization of Investment Leading to Development (BUILD) Act; a $113 \mathrm{mln}$ USD Indo-Pacific investment allocation; and Prosper Africa — which admittedly had aims beyond countering China's BRI. Due to space constraints, this article covers only the first two.

The BUILD Act came into effect in early October 2018. It created a new developmentfocused agency called the IDFC, which replaced the Overseas Private Investment Corporation (OPIC), assumed certain functions from the US Agency for International Development (USAID), and has new tools (e.g., the authority to take equity stakes) to support private sector investment in select projects in a wide range of developing countries with loans, insurance, and investments to facilitate such countries transitioning into market economies. For many, what is most noteworthy about the IDFC is its significantly larger budget (60 billion USD) versus OPIC's (30 billion USD). Observers leave no doubt that one of the motivations driving the

${ }^{41}$ National Security Strategy of the United States of America // US White House. December 2017. P. 47. URL: https://trumpwhitehouse.archives.gov/wp-

content/uploads/2017/12/NSS-Final-12-18-2017-0905.pdf (accessed: 29.01.2021).

42 Ibid.

${ }^{43}$ United States Strategic Framework for the IndoPacific [Secret] // US White House. February 15, 2018. P. 10, 15. URL: https://trumpwhitehouse.archives.gov/wpcontent/uploads/2021/01/IPS-Final-Declass.pdf (accessed: 29.01.2021). passage of the BUILD Act was the desire to create a meaningful alternative to China's BRI and infrastructure schemes ${ }^{44}$.

The $113 \mathrm{mln}$ USD investment allocation, announced by Mr. Pompeo in summer 2018, intended to support technical assistance, legal support, insurance, and risk mitigation, project assessment and financing programs, and policy advice initiatives relating to the digital economy, infrastructure, and energy in the Indo-Pacific. Mr. Pompeo labeled these funds "a down payment on a new era in US economic commitment to peace and prosperity in the IndoPacific region" and a component of the administration's efforts to oppose any country that sought to dominate the Indo-Pacific. Many experts concluded that the initiative targeted China and also took the view that the program was puny in scale and overly vague ${ }^{45}$.

\section{Onward with Others}

Another prong in the Trump administration's response to the BRI was closer coordination, mostly as a follower rather than leader, with allies such as Japan, perceived partners like India, and friendly groupings such as the US - Japan - Australia - India Quadrilateral (hereinafter the "Quad") and the

${ }^{44}$ See: Chaudhri J., Gurdak M.P., Willis G.H. How Will New U.S. International Development Finance Corporation Help American Companies // Jones Day Commentaries. October 2018. URL: https:/www.jonesday.com/en/insights/ 2018/10/how-will-new-us-international-development-finance (accessed: 19.02.2021); Runde D.F., Bandura R. The BUILD Act has Passed: What's Next // CSIS Critical Questions. October 12, 2018. URL: https://www.csis.org/ analysis/build-act-has-passed-whats-next (accessed: 19.02.2021).

${ }^{45}$ See: Indo-Pacific Business Forum Highlights // U.S. Chamber of Commerce. July 30, 2018. URL: https://www.uschamber.com/event/indo-pacific-businessforum-highlights (accessed: 19.02.2021); U.S. Plans \$113 Million 'Down Payment on a New Era' in Indo-Pacific: Pompeo // Reuters. July 30, 2018. URL: https://www.reuters.com/article/us-usa-trade-pompeo/u-splans-113-million-down-payment-on-a-new-era-in-indopacific-pompeo-idUSKBN1KK1NP (accessed: 19.02.2021); King A. US Answers Belt and Road with Own IndoPacific Investment Plan // Nikkei Asia. July 30, 2018. URL: https://asia.nikkei.com/Politics/International-relations/ US-answers-Belt-and-Road-with-own-Indo-Pacificinvestment-plan (accessed: 19.02.2021). 
Trilateral Infrastructure Group Working Group (consisting of Japan, Australia, and the US). These interactions sought to challenge China's BRI in several ways. The first was to shine the light on the BRI, COFDI, and infrastructure's shortcomings and, relatedly, advance more principled infrastructure and FDI activities. The second promoted alternatives to Chinese development schemes. The third was to stimulate increased funding by the Quad countries and international financial institutions such as the ADB which would, in turn, support these higher standards and counter initiatives.

It was in November 2017 when we began to witness visible US collaboration with Japan on the BRI in tandem with Trump's visit to Asia that year. Specifically, US OPIC signed Memorandums of Understanding (MoUs) with the Japan Bank for International Cooperation and Nippon Export and Investment Insurance; the US Trade and Development Agency concluded an agreement with Japan's Ministry of Economy, Trade, and Industry; and the two countries launched an energy partnership for developing regions. These and later MoUs and agreements sought to promote cooperation on and boost funding for mutually agreeable projects to increase affordable, open, transparent, sustainable, and productive investment in infrastructure, energy, and other sectors ${ }^{46}$. The US also was supportive of Japan's 2015 PQII which stresses the need for projects to take due account of debt sustainability, quality, local employment, social and environmental effects, and proper procurement processes; the adoption of PQII principles at the G7 Ise-Shima Summit in 2016;

${ }^{46}$ See: Tiezzi S. In Japan, Trump and Abe Offer Alternatives to China's 'Belt and Road' // The Diplomat. November 8, 2017. URL: https://thediplomat.com/2017/ 11/in-japan-trump-and-abe-offer-alternative-to-chinas-beltand-road (accessed: 19.02.2021); Basu T. Japan's Belt and Road Puzzle, Decoded // The Diplomat. February 28, 2018. URL: https://thediplomat.com/2018/02/japans-beltand-road-puzzle-decoded (accessed: 19.02.2021); United States and Japan Sign Memorandum of Cooperation Strengthening Energy and Infrastructure Finance and Market Building // US Department of the Treasury. February 4, 2020. URL: https://home.treasury.gov/news/ press-releases/sm894 (accessed: 29.01.2021). and the embrace of PQII principles at the 2019 G20 summit ${ }^{47}$.

Shifting to India, the Trump administration was supportive of Indian concerns about the BRI [Rajagopalan 2020]. For example, the joint statement issued after Indian Prime Minister Narendra Modi visited Trump in June 2017 in Washington stressed agreement on the principle that "regional economic connectivity [should be enhanced] through the transparent development of infrastructure and the use of responsible debt financing practices... and call on other nations in the region to adhere to these principles" ${ }^{\prime 4}$. Three months later, then US Defense Secretary Mattis seconded Indian claims that the BRI traversed through disputed territory ${ }^{49}$. In the aforenoted October 2017 policy speech, former Secretary of State Tillerson stressed that the US and India "should be in the business of equipping other countries to defend their sovereignty, build greater connectivity, and have a louder voice in a regional architecture" $"$. In 2019, Ambassador Wells opined, "we share India's concerns over projects that don't have an economic basis and that lead to countries ceding sovereignty" ${ }^{\prime \prime}$.

${ }^{47}$ See: Harris T. 'Quality Infrastructure': Japan's Robust Challenge to China's Belt and Road // War on the Rocks. April 9, 2019. URL: https://warontherocks.com/2019/04/ quality-infrastructure-japans-robust-challenge-to-chinasbelt-and-road (accessed: 19.02.2021). On US support for QII, see: Weatherby C. Next Steps for US - Japan Collaboration on Energy Infrastructure // East - West Center Asia-Pacific Issues. October 2020. No. 145. URL: https://www.jstor.org/stable/resrep26430 (accessed: 19.02.2021).

${ }^{48}$ Joint Statement - United States and India: Prosperity through Partnership // Government of India, Ministry of External Affairs. June 27, 2017. URL: https://www.mea.gov.in/bilateral-documents.htm?dtl/ 28560/Joint+Statement++United+States + and+India+Prosp erity+Through+Partnership (accessed: 19.02.2021).

${ }^{49}$ Defining Our Relationship with India for the Next Century: An Address by U.S. Secretary of State Rex Tillerson // CSIS. October 18, 2017. URL: https://www.csis.org/analysis/defining-our-relationshipindia-next-century-address-us-secretary-state-rex-tillerson (accessed: 29.01.2021).

${ }^{50}$ Wuthnow J. From Friend to Foe-Ish: Washington's Negative Turn on the Belt and Road Initiative // The Asan Forum. May 21, 2018. URL: www.theasanforum.org/fromfriend-to-foe-ish-washingtons-negative-turn-on-the-beltand-road-initiative (accessed: 19.02.2021).

${ }^{51}$ National Security Strategy of the United States of America // US White House. December 2017. URL: 
Turning to the multilateral front, there are several initiatives involving the members of the Quad. To illustrate, at the end of July 2018, the US, Australia, and Japan set up a grouping to "mobilize investment in projects", that featured "transparency, open competition, sustainability, adhering to robust global standards, employing the local workforce, and avoiding unsustainable debt burdens" ${ }^{\prime 52}$. In late November 2019, the US, Japan, and Australia launched the "Blue Dot Network". The program would give a stamp of approval to infrastructure projects meeting certain standards relating to inter alia inclusiveness, transparency, economic viability, environmental sustainability, compliance with international laws and regulations, and construction quality. The hope was such a certification would encourage private investors and multilateral institutions like the $\mathrm{ADB}$ to invest in projects $^{53}$.

\section{The Trump Administration's BRI Policy and its Drivers}

As extensively documented, almost all of Trump's tenure in office featured ongoing rhetorical attacks against the BRI and related

https:/trumpwhitehouse.archives.gov/wp-content/uploads/ 2017/12/NSS-Final-12-18-2017-0905.pdf (accessed: 29.01.2021); United States Strategic Framework for the Indo-Pacific [Secret] // US White House. February 15, 2018. URL: https://trumpwhitehouse.archives.gov/wpcontent/uploads/2021/01/IPS-Final-Declass.pdf (accessed: 29.01.2021); The Elements of the China Challenge // US DoS, Policy Planning Staff. November 2020. URL: https://www.state.gov/wp-content/uploads/2020/11/2002832-Elements-of-China-Challenge-508.pdf (accessed: 29.01.2021).

52 Obe M. US, Japan, and Australia Team Up on IndoPacific Building Push // Nikkei Asia. July 31, 2018. URL: https://asia.nikkei.com/Economy/US-Japan-and-Australiateam-up-on-Indo-Pacific-building-push (accessed: 19.02.2021).

${ }^{53}$ See: Regalado F. US 'Late' in Pushing Blue Dot to Counter China's Belt and Road // Nikkei Asia. November 22, 2019. URL: https://asia.nikkei.com/Politics/ International-relations/US-late-in-pushing-Blue-Dot-tocounter-China-s-Belt-and-Road (accessed: 19.02.2021); The U.S. Vision for the Indo-Pacific Region // US DoS. January 31, 2020. URL: https://2017-2021.state.gov/the-us-vision-for-the-indo-pacific-region-2/index.html (accessed: 29.01.2021); Kuo M.A. Blue Dot Network: The Belt and Road Alternative // The Diplomat. April 7, 2020. URL: https://thediplomat.com/2020/04/blue-dot-networkthe-belt-and-road-alternative (accessed: 19.02.2021).
Chinese activities. As well, the Trump administration began to incorporate references to the BRI into key American strategies such as its strategy for the Indo-Pacific. It further launched several initiatives on the development front such as the BUILD Act. Lastly, it increased cooperation with others such as Japan and joined in multilateral ventures like the Blue Dot Network. In terms of breadth and depth, the Trump administration's (relatively coherent) response was qualitative larger than the Obama administration's, with the bulk of activity taking place in 2017 and $2018^{54}$. Its reaction, though, certainly did not reflect anything akin to a supercharged response in terms of expenditures, arm twisting of American allies, or action against Chinese companies ${ }^{55}$. Analysts have advanced three main arguments to explain the Trump administration's BRI stance. One argument stresses the role of Trump as an individual. The second emphasizes the impact of domestic variables such as a policy community. The third focuses on "structural" factors, especially the US - China rivalry.

Analysts emphasizing the personality of Trump, consider how his personality, ideology, and worldviews might have played a role in his administration's reaction to the BRI. In regard to personality, they highlight his confrontational, narcissistic, and unpredictable style. With respect to ideology, they mention his America First doctrine, unwillingness to embrace traditional American policies towards allies, international institutions, and public goods, disdain for the extant neoliberal politico-economic order, disclination to pay attention to matters of democracy, human rights, and good governance, and dislike of bureaucrats ${ }^{56}$. As for worldviews,

${ }^{54}$ Ashbee [2020: 376] asserts the US strategy was incremental and a patchwork.

55 This view is shared by: Wuthnow J. From Friend to Foe-Ish: Washington's Negative Turn on the Belt and Road Initiative // The Asan Forum. May 21, 2018. URL: www.theasanforum.org/from-friend-to-foe-ish-washingtonsnegative-turn-on-the-belt-and-road-initiative (accessed: 19.02.2021).

${ }^{56}$ See: Bittner P. Trump's Wavering Stance on China's One Belt One Road // China US Focus. December 21, 2017. URL: https:/www.chinausfocus.com/foreign-policy/ trumps-wavering-stance-on-chinas-one-belt-one-road (accessed: 19.02.2021); Wuthnow J. From Friend to 
they note Trump's view of China as an economic predator and later economic and political threat [Boutin 2019: 17-18; Ashbee 2020: 379-380]. While definitely part of the story, an explanation spotlighting Trump has trouble explaining his administration's shift from a slightly accommodative to a hostile posture towards the BRI, his administration's relatively linear and bounded implementation of its adversarial policy (once adopted), and its increased cooperation over time with allies and partners to deal with the BRI challenge.

The domestic politics argument contends a "policy community" consisting of academics, consultants, government officials, researchers, and others shaped the Trump administration's agendas and policy choices. It specifically was behind the administration's turn against the BRI, changed attitudes towards the PRC, newfound willingness to work with allies and partners, support for the BUILD Act, and other policy dynamics [Ashbee 2020: 375-376, 392]. According to this line of thinking, Trump's shallow thinking and mercurial nature made him susceptible to advice while the policy community's different views about China, the BRI, and the suitability of different policies resulted in uneven policy implementation and the inadequate allocation of resources [Ashbee 2020: 392-394]. One defect with the policy community argument is the dearth of evidence that there was a community. Another is the lack of proof it exerted a decisive influence on Trump's BRI agenda and policy choices. Beyond this, while the argument may explain inconsistencies in some policy areas, it fails to explain consistency in other areas such as US rhetoric and strategy from 2017 onward.

Structural factors also shaped the Trump administration's BRI strategy and bounded its response toolkit. Per some, the overarching

Foe-Ish: Washington's Negative Turn on the Belt and Road Initiative // The Asan Forum. May 21, 2018. URL: $\quad$ www.theasanforum.org/from-friend-to-foe-ishwashingtons-negative-turn-on-the-belt-and-road-initiative (accessed: 19.02.2021); Lawrence S. et al. U.S. - China Relations // Congressional Research Service Report (R45898). September 3, 2019. URL: https://crsreports.congress.gov/ product/pdf/R/R45898 (accessed: 29.01.2021). See also: [Boutin 2019: 14-15; Sutter 2020: 143, 147-155]. structural factor shaping the administration's behavior was the US - China rivalry. The BRI fed into the rivalry (and the rivalry exacerbated anxieties about the BRI) because it was intimately associated with China's challenge to US primacy in various regions, US-dominated international institutions, and US championed norms. There also were fears that it would undermine US prestige. As well, there were worries that it would allow China to dominate states and resource and trade flows ${ }^{57}$.

For the school emphasizing structural factors, the US - China rivalry initially did not fuel US action against the BRI because Washington hoped China would help it with North Korea, the trade deficit, and other issues ${ }^{58}$. In short, the rivalry was not yet intense enough to influence its stance towards the BRI. For its part, the BRI did not exacerbate the rivalry. One reason was Washington's (reported) ignorance about its downsides. Another reason was that US companies and allies initially saw opportunities emanating from the $\mathrm{BRI}^{59}$. Ultimately, Washington's unrequited hopes for Chinese cooperation and dismay with PRC actions, increased awareness about the BRI's adverse

${ }^{57}$ See: LiveAtState with Tibor P. Nagy, Assistant Secretary of State for the Bureau of African Affairs // US DoS. December 21, 2018. URL: https://2017-2021. state.gov/liveatstate-with-special-representative-for-

ukraine-negotiations-kurt-volker-2/index.html (accessed: 29.01.2021); Wuthnow J. From Friend to Foe-Ish: Washington's Negative Turn on the Belt and Road Initiative // The Asan Forum. May 21, 2018. URL: www.theasanforum.org/from-friend-to-foe-ish-

washingtons-negative-turn-on-the-belt-and-road-initiative (accessed: 19.02.2021). See also: [Boutin 2019: 2-12; Sutter 2020: 143-145].

${ }^{58}$ Wuthnow J. From Friend to Foe-Ish: Washington's Negative Turn on the Belt and Road Initiative // The Asan Forum. May 21, 2018. URL: www.theasanforum.org/fromfriend-to-foe-ish-washingtons-negative-turn-on-the-beltand-road-initiative (accessed: 19.02.2021).

${ }^{59}$ See: Wuthnow J. From Friend to Foe-Ish: Washington's Negative Turn on the Belt and Road Initiative // The Asan Forum. May 21, 2018. URL: www.theasanforum.org/from-friend-to-foe-ish-washingtonsnegative-turn-on-the-belt-and-road-initiative (accessed: 19.02.2021); Gan N., Delaney R. United States under Donald Trump is Veering Away from China's Belt and Road // South China Morning Post. April 25, 2019. URL: https://www.scmp.com/news/china/article/3007504/unitedstates-under-trump-veering-away-chinas-belt-and-road (accessed: 19.02.2021). 
implications, courting of India, intensified antiPRC and anti-BRI sentiments in Washington, and a change in business and ally attitudes opened the door for a more aggressive response ${ }^{60}$.

The question emerges as to why the Trump administration did not respond even more aggressively given the aforementioned structural shifts. One analyst points to budgetary limits ${ }^{61}$. Another important constraint is US development ideology which since the 1970s has shunned large-scale infrastructure projects ${ }^{62}$. On top of this, this ideology stresses not just the superiority of mobilizing private rather than state capital, but also the use of non-monetary tools to catalyze development ${ }^{63}$. Illustrative of the US development ideology, during a background briefing, an unnamed Senior US DoS official answered a question about Chinese loan programs with the response, "we're not in a position to compete with China in terms of, like, offering the kind of infrastructure investment that China offers... we believe quite strongly that... investment needs to be led by the private sector" ${ }^{\prime 64}$.

\footnotetext{
${ }^{60}$ See: Hearing on China's Belt and Road Initiative: Five Years Later // United States-China Economic and Security Review Commission. January 25, 2018. URL: https://www.uscc.gov/hearings/chinas-belt-and-roadinitiative-five-years-later (accessed: 29.01.2021); Wuthnow J. From Friend to Foe-Ish: Washington's Negative Turn on the Belt and Road Initiative // The Asan Forum. May 21, 2018. URL: www.theasanforum.org/fromfriend-to-foe-ish-washingtons-negative-turn-on-the-beltand-road-initiative (accessed: 19.02.2021); Ford L. The Trump Administration and the 'Free and Open IndoPacific' // Brookings Foreign Policy Brief. May 2020. URL: https://www.brookings.edu/research/the-trumpadministration-and-the-free-and-open-indo-pacific (accessed: 19.02.2021).

${ }^{61}$ Wuthnow J. From Friend to Foe-Ish: Washington's Negative Turn on the Belt and Road Initiative // The Asan Forum. May 21, 2018. URL: www.theasanforum.org/fromfriend-to-foe-ish-washingtons-negative-turn-on-the-beltand-road-initiative (accessed: 19.02.2021).

62 Goodman M.P. et al. The Higher Road: Forging a U.S. Strategy for the Global Infrastructure Challenge // CSIS Report. April 23, 2019. P. 15-16. URL: https://www.csis.org/higherroad (accessed: 19.02.2021).

${ }^{63}$ U.S. Policy in the Indian Ocean Region // US DoS. August 20, 2018. URL: https://2017-2021.state.gov/u-spolicy-in-the-indian-ocean-region/index.html (accessed: 29.01.2021).

${ }^{64}$ Background Briefing on U.S. - Central Asian Relations // US DoS. December 13, 2019. URL:
}

\section{Conclusion}

This article has explored the US - China rivalry with a specific focus on the US response to the BRI under the Trump and Obama administrations. It first described the BRI before exploring and analyzing the US's reaction to China's BRI during the Obama presidency. Subsequently, it delved into the Trump administration's response, looking at its rhetoric, treatment of the BRI (as well as related Chinese infrastructure and investment activities) in its strategic doctrines, its launching of competitor development programs such as the BUILD Act, and its efforts to cooperate with others. It then moved into an analysis of various arguments about the variables shaping the US response to the BRI.

The article demonstrated that the Obama administration did respond to the BRI, but only in an extremely limited and mostly accommodative way. Reasons for this include a focus on other priorities such as Afghanistan, the absence of a feeling the BRI was threatening, and Obama's largely nonconfrontational views about the PRC. The BRI did not fuel the US China rivalry and the rivalry did not promote a negative US stance towards the BRI. The article showed that, in contrast, Washington adopted a more adversarial posture towards the BRI under Trump. This resulted from a mix of structural factors. Examples include increased US worries about China and the BRI; Washington's feeling cooperation with China would not deliver desired payoffs; and a shifting domestic political environment. Unlike Obama's time, the BRI stimulated the rivalry while the rivalry also supported a confrontational posture towards the BRI.

Writing in 2018 about US BRI policy, one analyst, Joel Wuthnow, forecast it would continue its "currently modestly antagonistic policy", adding a pivot in a more cooperative or competitive direction is also possible ${ }^{65}$. Later,

\footnotetext{
https://2017-2021.state.gov/background-briefing-on-u-scentral-asian-relations/index.html (accessed: 29.01.2021).

${ }^{65}$ Wuthnow J. From Friend to Foe-Ish: Washington's Negative Turn on the Belt and Road Initiative // The Asan Forum. May 21, 2018. URL: www.theasanforum.org/fromfriend-to-foe-ish-washingtons-negative-turn-on-the-beltand-road-initiative (accessed: 19.02.2021).
} 
another forecast the US would worry less about the BRI and devote more attention to its opportunities [Starr 2019: 79-91]. While we might expect less inflammatory rhetorical because of Biden's personality, ideology, and worldview, my analysis does not suggest a "pivot" in a more cooperative or competitive direction.

Various structural factors will drive Washington to maintain, within limits, a negative stance towards the BRI.

Firstly, it remains anxious about the challenge posed by China and the BRI.

Secondly, while it seeks cooperation with Beijing in areas like climate change, there is no evidence it feels restraint towards China is needed to help it accomplish its major aims.

Thirdly, it favors increased cooperation with allies and partners.

Fourthly, it appears to put great stress on infrastructure.

Fifthly, financial and ideational constraints will prevent massive development countermeasures. The business implications of my analysis are that non-Chinese companies still should be cautious about involving themselves in Chinese BRI projects.

Nonetheless, they may find opportunities by exploiting US counter initiatives.

As for analytical value, this article shows how structural factors can illuminate state policies, changes in them, and the bounded nature of policies.

One important question is if the global pandemic necessitates modifying the preceding forecast. It depends in large part on how it influences the BRI's future course. If, for example, the pandemic affects China's economy or that of participants in a notably adverse fashion such that it proves impossible to initiate new BRI projects or complete existing ones then the BRI ceteris paribus will become less threatening and thus should feature less prominently in the US - China rivalry. If, on the other hand, the pandemic spurs progress on the BRI - after all, BRI countries including
China will need to find ways to support growth - or catalyzes aspects of the BRI such as the Digital Silk Road, which is threatening to the US because it posits a world centered around Chinese technology and technology networks, then the BRI likely will escalate US - China tensions. Aside from this, if nationalistic pandemic-related measures like the US and China's dueling vaccine diplomacy intensifies the bilateral rivalry, then it is possible the US may view the BRI, which has a component known as the Health Silk Road, more negatively and feel a need to respond.

There are several limitations to the analysis herein. One limitation is that it was not possible to conduct interviews with relevant policymakers or evaluate key documents, both which will become feasible only with the passage of time. Due to space limitations of the paper, China's responses (or lack thereof) to US measures are not covered [Liu 2020]. They likely played some role in Obama and Trump's views of the BRI and China and their posture towards both. Yet another is that I have not been able to explore in depth, for reasons of time and space, less high profile, but still noteworthy US actions - e.g., the application of sanctions on a Chinese company involved in a BRI project during Trump's tenure in office. In future work, I will address these lacunas.

In two years, the BRI will be ten years old. For almost four years after its birth, Washington viewed it as a train potentially worth boarding. In 2017, however, it began to belittle the train as evil. It had to slow it; keep passengers away from it; and build alternatives to it. It never tried seriously to derail it, though. As this article demonstrates, internal and external structural factors explain much of these witnessed behaviors. They also suggest why Washington likely will keep chugging along mostly the same course under the Biden administration. The BRI will continue to stimulate, but not supercharge, the Sino-American rivalry and the rivalry will continue to support a negative US stance towards the BRI. 


\section{References / Библиографический список}

Ashbee, E. (2020). 'We don't drown our partners in a sea of debt': U.S. policy responses to China's Belt and Road Initiative. The Journal of American - East Asian Relations, 27(4), 374-400. https://dx.doi.org/10.1163/ $18765610-27040004$

Blanchard, J.-M.F. (2018a). China's Maritime Silk Road Initiative (MSRI) and Southeast Asia: A Chinese "pond" not "lake" in the Works. Journal of Contemporary China, 27(111), 329-343. https://dx.doi.org/10.1080/ 10670564.2018.1410959

Blanchard, J.-M.F. (2021a). Belt and Road Initiative (BRI) Blues: Powering BRI research back on track to avoid choppy seas. Journal of Chinese Political Science, 26(1), 235-255. https://dx.doi.org/10.1007/s11366-02009717-0

Blanchard, J.-M.F. (Eds.). (2018b). China's Maritime Silk Road Initiative and South Asia. A political economic analysis of its purposes, perils, and promise. Singapore: Palgrave Macmillan.

Blanchard, J.-M.F. (Eds.). (2019). China's Maritime Silk Road Initiative and Southeast Asia. Dilemmas, doubts, and determination. Singapore: Palgrave Macmillan.

Blanchard, J.-M.F. (Eds.). (2021b). China's Maritime Silk Road Initiative, Africa, and the Middle East. Feats, freezes, and failures. Singapore: Palgrave Macmillan.

Boutin, K. (2019). Challenging security: The United States and the Belt and Road Initiative. China and the World, 2(1), 1-23. https://dx.doi.org/10.1142/S259172931950007X

Chen, S. (2018). Regional responses to China's Maritime Silk Road Initiative in Southeast Asia. Journal of Contemporary China, 27(111), 344-361. https://dx.doi.org/10.1080/10670564.2018.1410960

Flint, C., \& Zhu, C. (2019). The geopolitics of connectivity, cooperation, and hegemonic competition: The Belt and Road Initiative. Geoforum, 99, 95-101. https://dx.doi.org/10.1016/j.geoforum.2018.12.008

Goldstein, A. (2020). US - China rivalry in the twenty-first century: Déjà vu and Cold War II. China International Strategy Review, 2, 48 - 62. https://dx.doi.org/10.1007/s42533-020-00036-w

Liu, F. (2020). The recalibration of Chinese assertiveness: China's responses to the Indo-Pacific challenge. International Affairs, 96(1), 9-27. https://dx.doi.org/10.1093/ia/iiz226

Lobell, S.E., Ripsman, N.M., \& Taliaferro, J.W. (2009). Neoclassical realism, the state, and foreign policy. Cambridge: Cambridge University Press.

Medeiros, E.S. (2019). The changing fundamentals of US - China relations. The Washington Quarterly, 42(3), 93-119. https://dx.doi.org/10.1080/0163660X.2019.1666355

Rajagopalan, R. (2020). Evasive balancing: India's unviable Indo-Pacific strategy. International Affairs, 96(1), 75-93. https://dx.doi.org/10.1093/ia/iiz224

Rathbun, B. (2008). A rose by any other name: Neoclassical realism as the logical and necessary extension of structural realism. Security Studies, 17(2), 294-321. https://dx.doi.org/10.1080/09636410802098917

Rose, G. (1998). Review: Neoclassical realism and theories of foreign policy. World Politics, 51(1), 144-172.

Starr, S.F. (2019). US perspectives on China's Belt and Road Initiative in Central Asia and the South Caucasus. International Studies, 56(2-3), 79—91. https://dx.doi.org/10.1177/0020881719851916

Sutter, R. (2020). Obama, Trump, and US politics and diplomacy towards Asia. In O. Turner \& I. Parmar (Eds.), The US in the Indo-Pacific (pp. 143-160). Manchester: Manchester University Press. https://dx.doi.org/ $10.7765 / 9781526135025.00017$

Wang, Y. (2016). Offensive for defensive: The Belt and Road Initiative and China's new grand strategy. The Pacific Review, 29(3), 455 - 463. https://dx.doi.org/10.1080/09512748.2016.1154690

Yung, C. (2021). The crisis in US - China bilateral security relations. Asian Perspective, 45(1), 33- 47. https://dx.doi.org/10.1353/apr.0.0002

Zhao, S. (2020). China's Belt-Road Initiative as the signature of President Xi Jinping diplomacy: Easier said than done. Journal of Contemporary China, 29(123), 319-335. https://dx.doi.org/10.1080/10670564.2019.1645483

\footnotetext{
About the author: Blanchard Jean-Marc F. - PhD, Distinguished Professor, School of Advanced International and Area Studies, East China Normal University, China; Executive Director, Mr. \& Mrs. S.H. Wong Center for the Study of Multinational Corporations, USA; e-mail: executive_director@mnccenter.org
}

Сведения об авторе: Бланшар Жан-Марк $Ф$. - доктор наук, заслуженный профессор Школы передовых международных и региональных исследований Восточно-китайского педагогического университета, Китай; исполнительный директор Центра изучения транснациональных корпораций им. г-на и г-жи С.Х. Вонг, СШA; e-mail: executive_director@mnccenter.org 